\title{
Pengaruh Suhu Air Perendaman terhadap Mutu Tepung Buah Mengkudu (Morinda citrifolia Linn.)
}

\author{
The Effect of Water Soaking Temperature on Noni Powder Quality \\ (Morinda citrifolia Linn.)
}

\author{
${ }^{1)}$ Asriani, ${ }^{2}$ Netti Herawati, ${ }^{3)}$ Halimah Husain \\ ${ }^{123)}$ Jurusan Kimia Fakultas Matematika dan Ilmu Pengetahuan Alam \\ Universitas Negeri Makassar, Jl. Dg Tata Raya Makassar, Makassar 90224 \\ Email:asriani028@gmail.com
}

\begin{abstract}
ABSTRAK
Buah mengkudu (Morinda citrifolia Linn.) merupakan salah satu buah tropis Indonesia dengan tingkat produktivitas yang tinggi. Tepung buah mengkudu dapat digunakan sebagai produk olahan yang dapat bertahan lama. Penelitian ini bertujuan untuk mengetahui pengaruh suhu air perendaman terhadap mutu tepung buah mengkudu. Jenis penelitian eksperimen meliputi preparasi sampel, perendaman, pengeringan, pengayakan dan uji mutu tepung. Aspek kimia meliputi karbohidrat, protein, kadar air, kadar abu dan uji organoleptik meliputi tekstur, aroma dan warna. Pembuatan tepung buah mengkudu menggunakan suhu perendaman bervariasi $5^{\circ} \mathrm{C}, 28^{\circ} \mathrm{C}, 100^{\circ} \mathrm{C}$, dan tanpa perendaman sebagai kontrol. Proses pembuatan tepung buah mengkudu yang memperoleh hasil baik mengacu pada SNI adalah perendaman dengan suhu $100^{\circ} \mathrm{C}$. Hasil analisis aspek kimia rendemen 10,1959\%, kadar karbohidrat 21,4553\%, Kadar Protein 9,2902\%, kadar air basis kering 8,9767\% basis basa $8,2403 \%$ dan kadar abu 3,4696\%. Uji organoleptik tepung berwarna kecoklatan, memiliki bau khas tidak tajam dan tekstur yang halus.
\end{abstract}

Kata kunci: Morinda citrifolia Linn., Mengkudu, Tepung, Perendaman

\section{ABSTRACT}

Noni (Morinda citrifolia Linn.) is one of Indonesian tropical fruit with a high level of productivity. Noni's powder could be utilized as a long-period product. This research aims to know the effect of water soaking temperature on the quality of noni powder. The Type of this experimental research include sample preparation, soaking, drying, sieving and powder quality test. The chemical aspects include protein, carbohydrates, water, ash, and organoleptic test such as texture, aroma, and color. Making noni powder needs some kinds of temperature such as $5^{\circ} \mathrm{C}, 28^{\circ} \mathrm{C}, 100^{\circ} \mathrm{C}$ and without soaking as control. The process of making noni powder which acquire good result refers to SNI is soaking with temperature $100^{\circ} \mathrm{C}$. Result of aspect chemistry have $10.1959 \%$ yield, $21.4553 \%$ carbohydrate, $9.2902 \%$ protein, $8.9767 \%$ dry basis water, $8.2403 \%$ water wet basis and $3.4696 \%$ ash content, and organoleptic test of brown powder have a little special aroma and soft texture.

Keywords: Morinda citrifolia Linn., Noni, Powder, Soaking 


\section{PENDAHULUAN}

Mengkudu memliki banyak kandungan senyawa aktif yang terdapat pada akar, daun, bunga dan buahnya. Bagian yang paling banyak dimanfaatkan adalah buahnya. Adapun senyawa aktif yang terdapat dalam buah mengkudu seperti senyawa terpenoid, scopoletin, xeronine dan proxeronine, zat anti-bakteri seperti acubin, asperuloside, alizarin beberapa zat antraquinon, dan beberapa jenis asam seperti asam askorbat (Vitamin C), asam kaproat, asam kaprilat dan asam kaprik (Pohan dan antara, 2001).

Senyawa kimia yang terdapat dalam buah mengkudu memiliki banyak manfaat bagi tubuh manusia, misalnya sebagai penyeimbang fungsi sel-sel tubuh, pemulih sel-sel tubuh, melancarkan peredaran darah, mengatasi penyakit jantung, diabetes mellitus, gangguan pernafasan, alergi, dan zat anti kanker yang dimiliki mengkudu paling efektif melawan selsel abnormal. Selain itu, dapat digunakan sebagai bahan pangan yang kaya akan antioksidan karena memiliki kandungan vitamin $\mathrm{C}$ yang cukup tinggi (Bangun dan Sarwono, 2002).

Buah mengkudu memiliki bau yang tajam dan kenampakan yang tidak menarik, sehingga sering tidak digunakan, bahkan dibeberapa masyarakat Sulawesi hanya dianggap sebagai sampah (Pohan dan antara, 2001).

Tepung sering digunakan untuk bahan tambahan pangan. Kandungan nutrisi buah mengkudu yang belum matang menurut Jones (2000) buah mengkudu mengandung karbohidrat $\quad 51,67 \%$ Jumlah kandungan karbohidrat yang dimiliki oleh buah mengkudu menjadi suatu alasan bahwa buah mengkudu dapat diolah menjadi tepung agar buah ini dapat digunakan secara optimal.

Tepung dari buah mengkudu merupakan produk inovasi baru yang saat ini masih kurang dikembangkan. Produk tepung buah mengkudu yang diperoleh dari hasil penelitian sebelumnya memilki mutu tepung mengkudu yang kurang baik. Segi fisik (warna yang coklat) sementara dari segi kimia (kadar air, kadar abu, kadar protein, dan kadar karbohidrat) belum diketahui seberapa besar jumlahnya sehingga belum dapat disimpulkan bahwa tepung tersebut bermutu baik

Proses perendaman dengan air panas juga dapat menghindari reaksi pencoklatan enzimatik yang terjadi pada produk olahan buah sehingga dapat mencegah warna coklat yang tidak diinginkan pada produk olahan. Proses ini digunakan dalam proses pembuatan tepung buah mengkudu.

Penelitian ini bertujuan untuk mengetahui pengaruh suhu air perendaman terhadap mutu tepung buah mengkudu (Morinda citrifolia Linn.)

\section{METODE PENELITIAN}

\section{A. Alat dan Bahan}

Alat-alat yang digunakan pada penelitian ini diantaranya wadah, pisau, alat-alat gelas berbagai ukuran, batang pengaduk, pipet tetes, gunting, oven, tanur, neraca analitik, spatula, buret, ayakan, alat destruksi, alat destilasi, Waterbath, Eksikator, 
blender, ayakan, gegep, kaca arloji, cawan porselin.

Bahan-bahan yang digunakan dalam penelitian ini di antaranya buah mengkudu (Morinda citrifolia Linn.), aquadest, indikator amilum, larutan Natrium Tiosulfat, selenium mixture, Asam Sulfat pekat $\left(\mathrm{H}_{2} \mathrm{SO}_{4}\right)$, Natrium Hidroksida $(\mathrm{NaOH})$, Asam Borat $\left(\mathrm{H}_{3} \mathrm{BO}_{3}\right) 4 \%$, larutan standar Asam Klorida $(\mathrm{HCl})$, indikator Bromocresol green (BCG), indikator fenolftalin (PP), dan lain-lain.

\section{B. Prosedur Kerja}

Proses pembuatan tepung buah mengkudu meliputi proses: sortasi buah mengkudu, pencucian, pemotongan, dan diberi perlakuan perendaman dengan variasi suhu air yang berbeda-beda yaitu (a)tanpa perendaman sebagai kontrol, (b)perendaman pada suhu $5^{\circ} \mathrm{C}$, (c)perendaman pada suhu $28^{\circ} \mathrm{C}$, (d)perendaman pada suhu $100^{\circ} \mathrm{C}$. Perendaman dilakukan selama 10 menit, selanjutnya pengeringan menggunakan oven pada suhu $55-60^{\circ} \mathrm{C}$ selama 5 hari, kemudian digiling dan diayak dengan ukuran ayakan 80 mesh.

Tepung buah mengkudu yang dihasilkan dari berbagai variasi perendaman dianalisis mutunya dari aspek kimia dan uji organoleptik. Aspek kimia meliputi penentuan kadar air menggunakan metode gravimetri, abu menggunakan metode gravimetri, karbohidrat menggunakan metode Luff Schoorl, dan protein menggunakan metode Kjeldahl. Uji organoleptik meliputi warna, tekstur, dan aroma.

\section{HASIL DAN PEMBAHASAN A. Hasil Penelitian}

Hasil penelitian menunjukkan bahwa tepung buah mengkudu dengan berbagai variasi suhu air perendaman memperoleh berat yang berbeda-beda yaitu tepung buah mengkudu (a) tanpa perendaman sebagai kontrol berat 124,5996gr, (b) perendaman suhu $5^{\circ} \mathrm{C}$ berat $165,5163 \mathrm{gr}$, (c) perendaman suhu $28{ }^{\circ} \mathrm{C}$ berat $114,6534 \mathrm{gr}$, (d) perendaman suhu $100^{\circ} \mathrm{C}$ berat 101,9594 gr.

Tabel 1. Data Hasil Analisis Mutu Kimia dalam 100 gr Tepung Buah Mengkudu

\begin{tabular}{ccccccc}
\hline \multirow{2}{*}{$\begin{array}{c}\text { Jenis } \\
\text { Perlakuan }\end{array}$} & $\begin{array}{c}\text { Rendemen } \\
(\boldsymbol{\%})\end{array}$ & $\begin{array}{c}\text { Kadar } \\
\text { Karbohidrat }\end{array}$ & $\begin{array}{c}\text { Kadar } \\
\text { Protein }\end{array}$ & \multicolumn{2}{c}{ Kadar Air $(\boldsymbol{\%})$} & Kadar \\
& & $(\boldsymbol{\%})$ & $(\boldsymbol{\%})$ & $(\mathbf{D B})$ & $(\mathbf{W B})$ & $\begin{array}{c}\text { Abu } \\
(\boldsymbol{\%})\end{array}$ \\
\hline $\mathrm{A}$ & $12,47 \%$ & 22,1883 & 6,4575 & 10,5982 & 9,5827 & 5,0933 \\
\hline $\mathrm{B}$ & $16,55 \%$ & 20,0108 & 7,9210 & 10,0166 & 9,1044 & 5,9550 \\
\hline $\mathrm{C}$ & $11,46 \%$ & 23,7151 & 7,3138 & 13,2956 & 11,7364 & 5,2163 \\
\hline $\mathrm{D}$ & $10,20 \%$ & 21,4553 & 9,2902 & 8,9767 & 8,2403 & 3,4696 \\
\hline
\end{tabular}


Tabel 2. Data Hasil Rata-rata Uji Organoleptik Pada Tepung Buah Mengkudu

\begin{tabular}{cccc}
\hline \multirow{2}{*}{ Jenis Perlakuan } & Warna (skor) & Tekstur (skor) & Aroma (skor) \\
\hline A & 3,2857 & 3,3572 & 3,5715 \\
\hline B & 3,0715 & 3,5714 & 3,7857 \\
\hline C & 3,5715 & 3,2857 & 3,5358 \\
\hline D & 4,3572 & 3,5714 & 4,0000 \\
\hline
\end{tabular}

B. Pembahasan

\section{Pembutan Tepung Buah Mengkudu}

Tepung buah mengkudu dibuat dari buah mengkudu segar, utuh, mulus, buah keras atau belum ranum, dan berukuran sedang. Setelah proses pemotongan dilakukan perlakukan proses perendaman dengan beberapa variasi suhu air perendaman. Proses perendaman ini bertujuan menghasilkan produk tepung buah mengkudu yang berwarna terang dan memilki mutu yang baik. Proses perendaman ini dilakukan selama 10 menit untuk meminimalkan vitamin dan mineral bermanfaat yang terkandung dalam mengkudu larut dalam air. Semakin lama interaksi buah dengan air, maka vitamin dan senyawa-senyawa yang mudah larut dalam air akan berkurang

$$
\text { Pada perlakuan (a) tanpa }
$$

perendaman, menghasilkan tepung buah mengkudu berbau khas mengkudu dan berwarna coklat yang menandakan telah terjadinya reaksi pencoklatan. Pencoklatan ini dapat disebabkan oleh senyawa antioksidan yang terdapat dalam buah mengkudu seperti senyawa-senyawa fenolik dan tanin yang mudah teroksidasi dengan oksigen dan menyebabkan warna coklat. Reaksi pencoklatan ini tergolong reaksi pencoklatan enzimatik yang melibatkan enzim polifenol oksidase. Senyawa fenolik, asam amino tirosin yang dimilliki oleh buah mengkudu menjadi susbstrak untuk enzim polifenol dan dengan bantuan oksigen membentuk melanin yang membuat produk tepung berwarna coklat. Secara normal, ketika buah atau sayuran dipotong atau memar, enzim dan fenol bereaksi dengan kehadiran oksigen membentuk produk yang kecoklatan (Winarno, 1984).

\begin{tabular}{lll}
\multicolumn{1}{r}{ Pada } & perlakuan (b) buah \\
mengkudu & setelah & direndam
\end{tabular} menggunakan air suhu $5^{\circ} \mathrm{C}$ menghasilkan penampakan menyerupai buah aslinya dimana daging buah masih bertekstur keras, tidak memiliki bau khas buah mengkudu, dan masih memiliki warna asli daging buah mengkudu yaitu putih, ini menunjukkan enzim polifenol oksidase tidak bekerja mengoksidasi senyawa-senyawa fenolik dalam buah mengkudu pada suhu tersebut. Setelah dilakukan pengeringan menggunakan oven diperoleh warna buah mengkudu yang jauh berbeda yaitu coklat kehitaman. Warna ini bisa disebabkan ketika pengeringan suhu daging buah perlahan naik, ketika mencapai suhu 
optimum dari enzim polifenol oksidase yang bekerja pada (suhu $30-40^{\circ} \mathrm{C}$ ). Enzim tersebut bekerja dengan optimal mengoksidasi senyawa-senyawa fenolik dan asam amino tirosin dengan bantuan oksigen membuat buah mengkudu menjadi berwarna sangat coklat kemudian enzim tersebut terdekomposisi oleh suhu oven. Warna tepung yang dihasilkan lebih gelap dari warna tepung tanpa proses perendaman.

$\begin{array}{ccc}\text { Pada perlakuan (c) buah } \\ \text { mengkudu yang } & \text { direndam }\end{array}$
menggunakan air biasa (suhu $28^{\circ} \mathrm{C}$ ) selama 10 menit setelah perendaman penampakan buah menjadi sedikit lunak, sedikit berbau khas buah mengkudu, terdapat sedikit bercak berwarna coklat yang menunjukkan telah terjadinya reaksi pencoklatan beberapa saat, reaksi pencoklatan ini terjadi ketika buah dipotong sebelum perendaman dimana luas permukaan kontak buah mengkudu dengan udara sangat besar sehingga terjadi oksidasi sesaat sebelum buah direndam. Perendaman dengan suhu ini menghasilkan warna tepung yang berwarna coklat disebabkan karena reaksi pencoklatan yang bereaksi sesaat dan juga dari biji buah mengkudu yang berwarna coklat. Warna tepung yang dihasilkan lebih terang dari warna tepung tanpa proses perendaman.

Pada perlakuan (d) buah mengkudu yang direndam menggunakan air panas (suhu $100^{\circ} \mathrm{C}$ ) selama 10 menit setelah perendaman penampakan buah menjadi sangat lunak, terdapat bau khas dari buah mengkudu, dan berwarna pucat. Hasil ini menunjukkan tidak terjadinya reaksi pencoklatan disebabkan pada suhu tersebut enzim polifenolase telah terdekomposisi yang menyebabkan enzim tersebut menjadi rusak dan tidak dapat bekerja mengoksidasi senyawasenyawa fenolik dan asam amino tirosin. Oleh karena itu, diperoleh warna tepung putih kecoklatan, warna kecoklatan ini disebabkan warna dari biji bauh mengkudu yang berwarna coklat. Warna tepung yang dihasilkan jauh lebih terang dari warna tepung tanpa proses perendaman.

\section{Uji Mutu Tepung}

Mutu tepung dinilai dari aspek kimia yang meliputi kadar air, kadar abu, kadar karbohidrat, kadar protein dan uji oerganoleptik meliputi terkstur, aroma, dan warna.

\section{a. Rendemen}

Berdasarkan pada Tabel 1
dapat dilihat bahwa perlakuan perendaman dengan suhu $5^{\circ} \mathrm{C}$ yang memberikan hasil rendemen yang lebih tinggi. Hal ini disebabkan setelah direndam dengan air dingin ini menunjukkan kandungan buah mengkudu tidak banyak yang hilang.

Pada perlakuan perendaman dengan suhu $100^{\circ} \mathrm{C}$ yang memberikan hasil rendemen yang paling sedikit, disebabkan perendamanan dengan suhu panas menyebabkan banyak bagian dari buah mengkudu yang terlarut dan terdegradasi dengan suhu panas sehingga mempengaruhi berat dari buah mengkudu yang telah direndam. Rendahnya rendemen juga dapat disebabkan ketika proses 
penghalusan buah menggunakan blender terdapat beberapa bagian yang sudah tidak dapat dihaluskan menyebabkan berkurangnya persen rendemen.

\section{b. Kadar Karbohidarat}

\section{Berdasarkan Tabel 1} perlakuan dengan perendaman air suhu ruang menghasilkan kadar karbohidrat tertinggi dari perlakuan yang lainnya yaitu $23,7151 \%$. Kadar karbohidrat dalam 100 gr buah mengkudu adalah 2,20\% (Jones, 2000). Terjadinya peningkatan jumlah karbohidrat pada perlakukan perendaman pada air suhu ruang dapat disebabkan ketika proses sortasi buah terdapat buah yang tidak sesuai standar. Ke-empat perlakuan tidak memenuhi syarat kadar karbohidrat yang baik dalam tepung menurut SNI 01-2973-1992 yaitu minimum $70 \%$.

Rendahnya kadar karbohidrat yang diperoleh dapat disebabkan pada proses pengolahan seperti perendaman pada suhu tinggi menyebabkan karbohidrat yang terikat pada air akan ikut menguap saat pengeringan, sehingga apabila banyak kadar air yang lepas maka kadar karbohidrat akan banyak yang lepas bersama dengan uap air (Ayu, 2014). Selain itu, dalam proses penentuan kadar karbohidrat menggunakan metode hidrolisis pati. Sedangkan buah mengkudu lebih banyak memiliki kandungan serat daripada kandungan pati, hal ini juga dapat menyebabkan jumlah kadar karbohidrat yang diperoleh rendah.

\section{c. Protein}

Berdasarkan Tabel 1 pembuatan tepung dengan perlakuan $5^{\circ} \mathrm{C}$ memenuhi standar yang telah ditetapkan oleh SNI 3751:2009 minimum $7 \%$. Jumlah protein yang tidak terlalu jauh beda disebabkan terjadinya denaturasi protein ketika dikeringkan menggunakan oven dimana protein dapat terdenaturasi pada suhu $50-80^{\circ} \mathrm{C}$. Penurunan protein ini juga dapat disebabkan oleh aktifitas enzim polifenol oksidase.

Enzim polifenol oksidase selain menyebabkan pencoklatan juga dapat menyebabkan menurunkan kadar protein. Enzim polifenol oksidase dengan katalis oksigen membentuk senyawa radikal orto-kuinon. Senyawa orto-kuinon tersebut sangat reaktif dan apabila bereaksi dengan protein dapat membentuk senyawa kompleks yang melibatkan asam amino lisin yang terkandung dalam mengkudu. Selain itu senyawa kompleks proteinpolifenol tersebut sulit ditembus oleh enzim protease sehingga daya cerna proteinnya juga rendah. Sehingga ketersediaan protein akan menurun (Palupi dkk, 2007).

Pada proses perendaman suhu $100^{\circ} \mathrm{C}$ enzim polifenol oksidase telah terdekomposisi sehingga, tidak dapat lagi bekerja dan diperoleh kandungan protein yang lebih tinggi dari perlakukan lainnya. Proses perendaman dengan suhu $100^{\circ} \mathrm{C}$ merupakan proses perendaman yang paling baik dilakukan untuk memperoleh tepung yang kaya protein. 


\section{d. Kadar Air}

Berdasarkan Tabel 1. perlakuan perendaman dengan air suhu $100^{\circ} \mathrm{C}$ memberikan hasil yang paling rendah yaitu basis kering $8,9767 \%$ dan basis basa $8,2403 \%$. Semakin rendah kadar air suatu tepung makan daya simpannya akan semakin lama karena mikroba dan bakteri sulit untuk berkembang biak (Winarno, 2004). Menurut SNI 3751:2009 kadungan kadar air dalam tepung maksimal $14,5 \%$ ini menunjukkan pembuatan tepung dengan proses perendaman memenuhi standar SNI.

Rendahnya kadar air yang disebabkan perlakuan suhu tinggi akan membuat kadar air yang terkandung dalam daging buah merembes keluar dari daging buah dan menguap, sehingga jumlah air yang terdapat dalam daging buah berkurang dan menghasilkan kadar air yang rendah. Semakin rendah kadar air semakin baik karena dapat memperpanjang umur simpanan bahan pangan. Proses perendaman yang paling baik dilakukan untuk memperoleh bahan pangan dengan kadar air yang rendah dan dapat bertahan lama adalah proses perendaman dengan suhu air perendaman $100^{\circ} \mathrm{C}$.

\section{e. Kadar Abu}

Berdasarkan Tabel 1. pada perlakuan perendaman dengan air dingin dan perendaman dengan air biasa mendapatkan hasil yang lebih tinggi yaitu 5,950\% dan 5,2163\%. Hal ini disebabkan air yang digunakan untuk perendaman memiliki kandungan mineral anorganik yang sulit larut pada suhu perendaman tersebut sehingga mineral anorganik yang terdapat dalam air masuk ke dalam jaringan sel. Sedangkan untuk perlakuan perendaman menggunakan air panas menghasilkan hasil yang lebih baik yaitu 3,4696 \%. Hal ini disebabkan dalam keadaan panas banyak mineral anorganik yang terdapat dalam buah mengkudu juga dalam air, telah larut dalam perendaman dengan suhu tersebut.

Kadar yang telah ditetapkan SNI maksimal 5\%. Dari hasil penelitian kadar abu yang terbaik adalah perendaman dengan suhu panas $\left(100^{\circ} \mathrm{C}\right) \quad$ yaitu $3,4696 \%$. Ini menunjukkan kadar abu dari tepung buah mengkudu dengan perendaman ini telah memenuhi standar yang telah ditetapkan.

\section{Organoleptik}

a. Warna

Berdasarkan Tabel 2 warna tepung buah mengkudu tanpa perendaman sebagai kontrol mendapat skor rata-rata panelis sebesar 3,2857 yang berarti netral atau tepung ini dapat diterima oleh panelis. Warna tepung dengan perendaman yang air dingin memiliki skor terrendah yaitu 3,0715. Hal ini disebabkan warna dari tepung ini berwarna coklat yang sangat gelap yang disebabkan oleh reaksi pencoklatan enzimatik tetapi, warna tepung ini masih bisa diterima oleh panelis. Sedangkan warna tepung dengan perendaman air panas memiliki skor 4,3572 yang menujukkan tepung ini disukai oleh panelis karena tepung dengan perlakuan ini berwarna putih kecoklatan ini disebabkan enzim 
polipenolase yang bekerja ketika buah telah dipotong, tidak dapat bekerja lagi karena telah terdenaturasi oleh suhu panas ketika buah direndam sehingga menghasilkan warna yang lebih terang. Warna coklat dari produk tepung buah mengkudu juga disebabkan oleh mengkudu memiliki asam amino tirosin yang dapat menciptakan melanin.

Perubaha warna yang bervariasi ini disebabkan oleh kondisi optimum enzim polienol oksidase, berada pada rentang suhu $30-40^{\circ} \mathrm{C}$ sehingga semakin tinggi suhu yang digunakan maka akan menghasilkan warna yang lebih terang karena enzim tersebut tidak dapat bekerja disuhu tinggi. Proses perendaman pada suhu $100^{\circ} \mathrm{C}$ merupakan suhu perendaman yang baik untuk memperoleh warna tepung yang lebih terang.

\section{b. Aroma}

Berdasarkan Tabel 2 aroma tepung buah mengkudu dengan perendaman menggunakan air biasa memiliki skor terrendah yaitu 3,2857 ini disebabkan suhu air biasa yang tidak terlalu dingin dan tidak terlalu panas sangat memudahkan senyawasenyawa volatil dalam buah mengkudu seperti asam kaprilat, asam kaprat dan asam kaproad untuk menguap sehingga menghasilkan bau khas buah mengkudu yang tajam dan kurang digemari oleh panelis, tetapi aroma ini masih bisa diterima oleh panelis.

Aroma khas yang ada pada tepung dengan perlakuan suhu rendah menghasilkan bauh khas mengkudu yang tidak terlalu tajam disebabkan perendaman dengan suhu rendah sanyawa-senyawa volatil yang terkandung dalam buah mengkudu tidak terlalu dapat berintraksi disebabkan perlakuan pada suhu rendah senyawa-senyawa tidak dapat bergerak dengan bebas. Hal ini dikarenakan dengan suhu dingin molekul-molekul $\quad \mathrm{H}_{2} \mathrm{O}$ bergerak lamban sehingga tumbukan yang dihasilkan sedikit dan sulit untuk berinteraksi dengan senyawa-senyawa volatile tersebut, sedangkan pada perlakuan dengan suhu tinggi senyawa volatil yang menyebabkan bau berkontraksi dengan cepat sehingga senyawa ini banyak yang menguap ketika perendaman. Proses perendaman pada pembuatan tepung buah memngkudu tidak berpengaruh besar terhadap aroma, ini dapat dilihat dari data panelis yang diperoleh tidak terlalu tajam dan tidak berbeda jauh.

\section{c. Tekstur}

Berdasarkan Tabel 2 tekstur dengan perlakuan perendaman dengan air dingin memiliki skor lebih tinggi daripada kontrol, sedangkan perendaman menggunakan air panas memiliki tekstur yang paling baik dan paling disukai panelis dengan skor 4,0000 .

Tekstur tepung dipengaruhi oleh jumlah ulangan ketika dihaluskan menggunakan blender, sehingga tepung yang beberapa kali diblender karna belum lolos dari saringan menghasilkan tekstur yang lebih lunak. Selain itu dipengaruhi oleh kadar air yang dimiliki oleh tepung tersebut tepung yang memiliki kadar air yang tinggi akan menghasilkan tekstur yang 
lebih lunak. Tepung yang lunak juga dipengaruhi oleh kadar protein semakin tinggi kadar protein maka tepung tersebut akan semakin lunak dan dapat mengembang dengan baik.

\section{KESIMPULAN DAN SARAN}

\section{A. Kesimpulan}

Berdasarkan hasil penelitian yang diperoleh dapat disimpulkan bahwa suhu perendaman berpengaruh terhadap mutu tepung buah mengkudu baik secara kimia dan berpengaruh sedikit terhadap uji organoleptik. Suhu perendaman yang paling baik digunakan adalah perendaman dengan menggunakan air panas (suhu $100^{\circ} \mathrm{C}$ ) memperoleh hasil dari uji organoleptik yaitu tepung berwarna putih kecoklatan, memiliki aroma khas tidak tajam dan tekstur yang halus. Rendemen 10,1959\% dan aspek kimia yaitu kadar karbohidrat 21,4553\%, kadar protein 9,2902\%, kadar air basis kering 8,9767\% basis basa 8,2403\% dan kadar abu 3,4696\%.

\section{B. Saran}

Adapun hal-hal yang
disarankan berkaitan dengan penyempurnaan penelitian ini adalah sebagai berikut:

1. Pada proses pengeringan sebaiknya menggunakan Cabinet Dryer yang penggunaanya lebih efektif dan dapat menggatur suhu dengan baik

2. Pada proses pemotongan buah mengkudu sebaiknya tidak terjadi kontak dengan udara yang dapat mengoksidasi senyawa-senyawa fenolik yang terdapat dalam buah mengkudu.

\section{DAFTAR PUSTAKA}

Ayu, D.C.an Sudarminto S.Y. 2014. Pengaruh Suhu Blansing dan Lama Perendaman terhadap Sifat Fisik Kimia Tepung Kimpul (Xanthosoma Sagittifolium). Jurnal Pangan dan Agroindustri Vol.2 No.2 p.110-12.Malang

Bangun, A. P. dan B. Sarwono, 2002. Sehat dengan Ramuan Tradisional, Khasiat dan Manfaat Mengkudu. Agro Media Pustaka. Jakarta.

Jones, W. 2000. Noni Blessing Holdings. Food Quality Analysis. Oregon.

Palupi, N.S., F.R. Zakaria dan E. Prangdimurti. 2007. Pengaruh Pengolahan terhadap Nilai Gizi Pangan. Departemen Ilmu \& Teknologi Pangan. Bogor.

Pohan, H.G. dan N.T. Antara. 2001. Pengaruh Penambahan Madu dan Asam Sitrat terhadap Karakteristik Minuman Fungsional dari Sari Buah Mengkudu. Forum Komunikasi IHP (4): 11-20.

Winarno, F.G. 1984. Enzim Pangan. Pusbangtepa. Bogor.

Winarno, F.G. 1993. Pangan Gizi, Teknologi dan Konsumen. Gramedia. Jakarta.

Winarno, F.G. 2004. Kimia Pangan dan Gizi. Gramedia. Jakarta. 